\title{
[ 281$]$
}

XIII. Note on the Generation of Aphides. By George Newport, Esq., F.R.S., Fellow of the Royal College of Surgeons, \&c. \& c. Communicated by the Secretary.

Read April 7th, 1846.

THE history of the Plant-louse, as ascertained by Leeuwenhoek, Bonnet, Reaumur, and others, is so generally known to naturalists, that it is almost an act of supererogation for any one merely to repeat the observations of those authorities; and we cannot expect to add much to the very ample details they have given. Yet the facts they have recorded respecting the generation of Aphides are in themselves so exceedingly curious, and at the same time are so unexplained by any hitherto received theory of generation deduced from observations on vertebrated animals, that I have been desirous of verifying these facts by direct experiment, preparatory to attempting hereafter to show their accordance with some universal law of reproduction. I trust therefore that I may now be permitted in this short note to bear testimony to the correctness of the observations of Leeuwenhoek, Bonnet, and Reaumur, on the mode of generation in the Aphides, although at present I can add but little to what has already been observed by those naturalists. The facts I have more particularly endeavoured to investigate, are: first, whether the Aphis is in reality viviparous at one season, and oviparous at another ? and next, whether the supposed ova are deposited as true eggs; or whether, as imagined by some observers, they are only capsules designed to protect the already formed embryos during the winter season?

With these objects in view, I selected the Aphis of the Rose, as best fitted for the inquiry. In the beginning of November 1842, the young shoots of a rose-tree, that had remained in the open air during the whole of the preceding summer, were thickly covered with Aphides, amongst which I had not yet seen any winged specimens; neither had any of the females yet deposited ova. The rose-tree was placed in the window of an apartment in which there was 
no fire, and where the temperature ranged from about $45^{\circ} \mathrm{Fahr}$. to $50^{\circ} \mathrm{Fahr}$. In the second week of November, as the temperature of the season became cooler, I first noticed several specimens with rudiments of wings, and a few days afterwards these cast their skins and became fully developed. Most of these individuals were males. At this time there were also a great many very young specimens. On the 30th of November the number of winged individuals had greatly increased; there were many with only the rudiments of wings; and there was also a great abundance of black oval eggs distributed everywhere on the young shoots of the plant, not only on the leaf-buds, but on the stems of the leaves and branches. I saw an Aphis at that moment bearing two eggs at the extremity of her body. On placing one of these beneath the microscope, I was quickly assured of its real nature: it was not a capsule that included a ready-formed embryo, but a true egg. When first deposited the egg is of an orange-yellow colour, but it soon acquires a much darker hue, and ultimately becomes of a deep shining black. The colour is entirely dependent on the pigment of the shell, and is much darker in some specimens than in others. The eggs are firmly glued to the plant, and are not easily removed. The egg of the Aphis is similar to that of other insects: it is composed of an orangecoloured yelk, formed of yellow nucleated cells, and surrounded by a very slight quantity of transparent vitelline fluid. It contains also a very large germinal vesicle with a distinct macula or nucleus. This vesicle is three or four times as large as the cells that compose the yelk, and, unlike that of most other impregnated eggs of insects, does not disappear until some time after the egg is deposited. The vesicle is so persistent, that in one instance, in which I examined an egg shortly after it came from the body of the Aphis, it did not disappear for several seconds after the egg was crushed under the microscope.

Wishing to observe the deposition of more eggs, I selected four specimens of the Aphis for experiment: two of these were males, which as yet were in the pupa state, and had only the rudiments of wings; the other two were large apterous females; these were placed on a detached branch of the rose, inclosed in a stoppered glass vessel, and removed to an apartment, in which the temperature ranged from $55^{\circ} \mathrm{Fahr}$. to about $60^{\circ}$. Fahr. On the 2 nd of December, when the temperature of the air of the room was $58^{\circ} \mathrm{Fahr}$., I was 
surprised to find that these specimens were again producing living young. One of the large apterous females had already produced its living offspring, and the other was at that very moment in the act of parturition. The posterior part of the body of a young Aphis was then protruding from that of the parent, and was quickly followed by the remainder of the body, the thorax - and the legs. When these parts had passed, there was a slight cessation of parturient action, the head being still retained in the vaginal passage. The disengagement of the head seemed to be the slowest part of the process. The manner in which the parent rid herself of the new-born Aphis was deserving of notice. When the little insect was almost entirely extruded from her body, it clung with its feet to the plant; while the female Aphis, at short intervals, gradually elevated her body, and with a slight jerk seemed to labour to remove it. The young Aphis repeatedly missed its hold, but quickly regained it, and was thus as it were partially dragged forth. The head, with its small black eyes, parts of the mouth, and the antennæ, were thus gradually withdrawn, but I could not detect any fœtal coverings removed with them. The whole process of birth occupied about five minutes. Immediately after the young had escaped from the parent, it turned about on the leaf and moved very slowly, while the female plunged her proboscis into the plant to take food after her exertion.

These brief observations confirm the statements of former naturalists, that the Aphides deposit at one period true ova, and at others produce living young; and they lead us hereafter to inquire more particularly respecting the circumstances which accelerate the one, or retard the other form of development. 


\section{$2 \mathrm{BHL}$ Biodiversity Heritage Library}

Newport, George. 1847. "Note on the Generation of Aphides." Transactions of the Linnean Society of London 20, 281-283.

https://doi.org/10.1111/j.1096-3642.1846.tb00421.x.

View This Item Online: https://www.biodiversitylibrary.org/item/19393

DOI: https://doi.org/10.1111/j.1096-3642.1846.tb00421.x

Permalink: https://www.biodiversitylibrary.org/partpdf/22993

\section{Holding Institution}

Natural History Museum Library, London

\section{Sponsored by}

Natural History Museum Library, London

\section{Copyright \& Reuse}

Copyright Status: Public domain. The BHL considers that this work is no longer under copyright protection.

This document was created from content at the Biodiversity Heritage Library, the world's largest open access digital library for biodiversity literature and archives. Visit BHL at https://www.biodiversitylibrary.org. 